\title{
is Research Square \\ Performance Analysis of Solar Chimney Power Plant from Geothermal Waste Heat Source a Case of Aluto-Langano, Ethiopia.
}

\author{
Tereche Getnet \\ Bahir Dar University \\ Aschale Getnet ( $\square$ useaschu@gmail.com ) \\ Bahir Dar University
}

\section{Research Article}

Keywords: solar chimney, collector efficiency, thermal simulation

Posted Date: April 26th, 2021

DOl: https://doi.org/10.21203/rs.3.rs-342471/v1

License: (c) (1) This work is licensed under a Creative Commons Attribution 4.0 International License.

Read Full License 


\title{
Performance Analysis of Solar Chimney Power Plant from Geothermal Waste Heat Source a Case of Aluto-Langano, Ethiopia.
}

\author{
Tereche Getnet ${ }^{\mathrm{a}}$, Aschale Getnet ${ }^{\mathrm{b}}$ * \\ a Lecturer, Faculty of Mechanical and Industrial Engineering, Bahir Dar Institute of \\ Technology - Bahir Dar University, Bahir Dar, Ethiopia. \\ $\mathrm{b}$ Lecturer, Faculty of Mechanical and Industrial Engineering, Bahir Dar Institute of \\ Technology - Bahir Dar University, Bahir Dar, Ethiopia.
}

\begin{abstract}
In this paper, the transient thermal simulation on working fluid of solar updraft power plant using waste water was investigated to characterize the enhancement by numerical and theoretical method. Numerical solution technique used to solve a differential equation form of governing equations using finite difference discretization scheme. Most of the researches done on geometrical parameters to perform the mathematical modeling. This paper combines some of the above improvements on the performance of plant and combines them with new idea of heat source as waste heat in Aluto Langano geothermal power plant. Moreover, this study using dimensions of plant constructed in Manzanares, Spain height of chimney $=194.6 \mathrm{~m}$, diameter of collector=244 $\mathrm{m}$, diameter of chimney $=10.16 \mathrm{~m}$.

The obtained result, the collector temperature increases by $7{ }^{\circ} \mathrm{C}$, the pressure potential is found 182.82 $\mathrm{Pa}$, the pressure drop on the turbine was $121.88 \mathrm{~Pa}$, the pressure loss was $60.94 \mathrm{~Pa}$ and the power output $123.59 \mathrm{~kW}$. As a result, the collector efficiency increases to $43.58 \%$ and the overall efficiency of plant to $0.242 \%$.
\end{abstract}

Key: solar chimney, collector efficiency, thermal simulation 


\section{Modeling of the Collector Roof, chimney and turbine}

Correspondingly, the following assumptions are taken to avoid complexity of mathematical model:

- Temperature rises in the solar collector is along radial direction [1]

- The collector roof and ground temperature has no variation along collector radius and thickness [2]

- Insignificant variation of velocity and temperature along chimney cross-section.

- The flow is one-dimensional, unsteady and inside parallel plate flow.

- Boussinesq assumption is valid for the airflow inside the tower [3]

- No heat loss throughout the chimney.

- The temperature at some depth below the ground surface is constant.

- There is no radial conduction in the ground surface

\subsection{Mathematical model for collector}

The mathematical model of the collector is done based on the figure 1.1 and figure 1.2. The energy balance equations are;

The continuity equation

$$
\frac{d}{d r}(\rho u A)=0
$$

Momentum equation

$$
-\rho u \frac{d u}{d r}=\frac{d p}{d r}+\rho g \frac{d h}{d r} .
$$

Energy equation

$$
\frac{\mathrm{dq}}{\mathrm{dr}}=-\frac{\mathrm{q}^{\prime \prime}}{\dot{\mathrm{m}}} \frac{d A}{d r}=c_{p} \frac{d T}{d r}+u \frac{d u}{d r}+g \frac{d h}{d r}
$$

State equations

$$
\frac{d p}{p}-\frac{d \rho}{\rho}-\frac{d T}{T}=0
$$




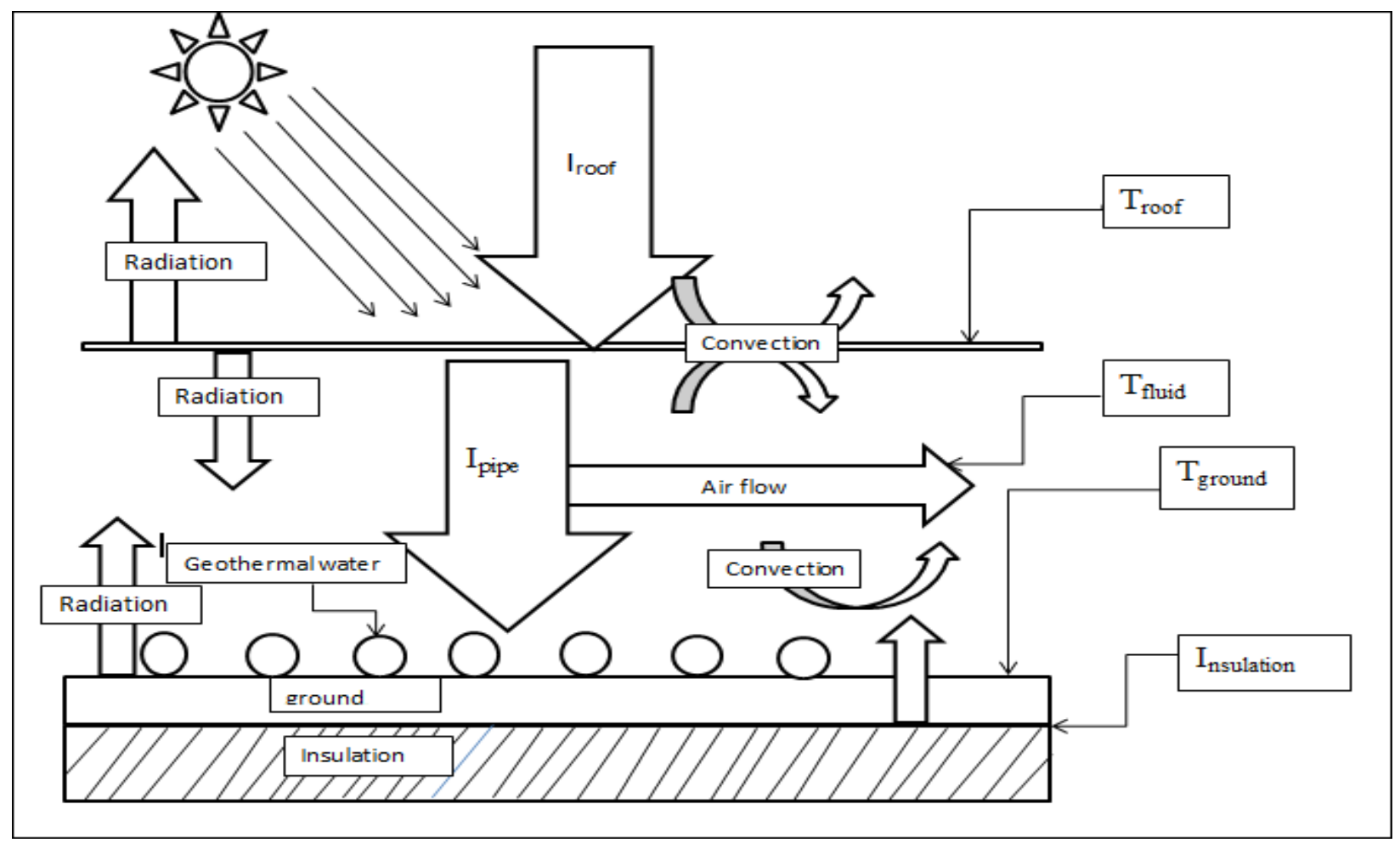

Figure 1. 1 Energy of collector roof

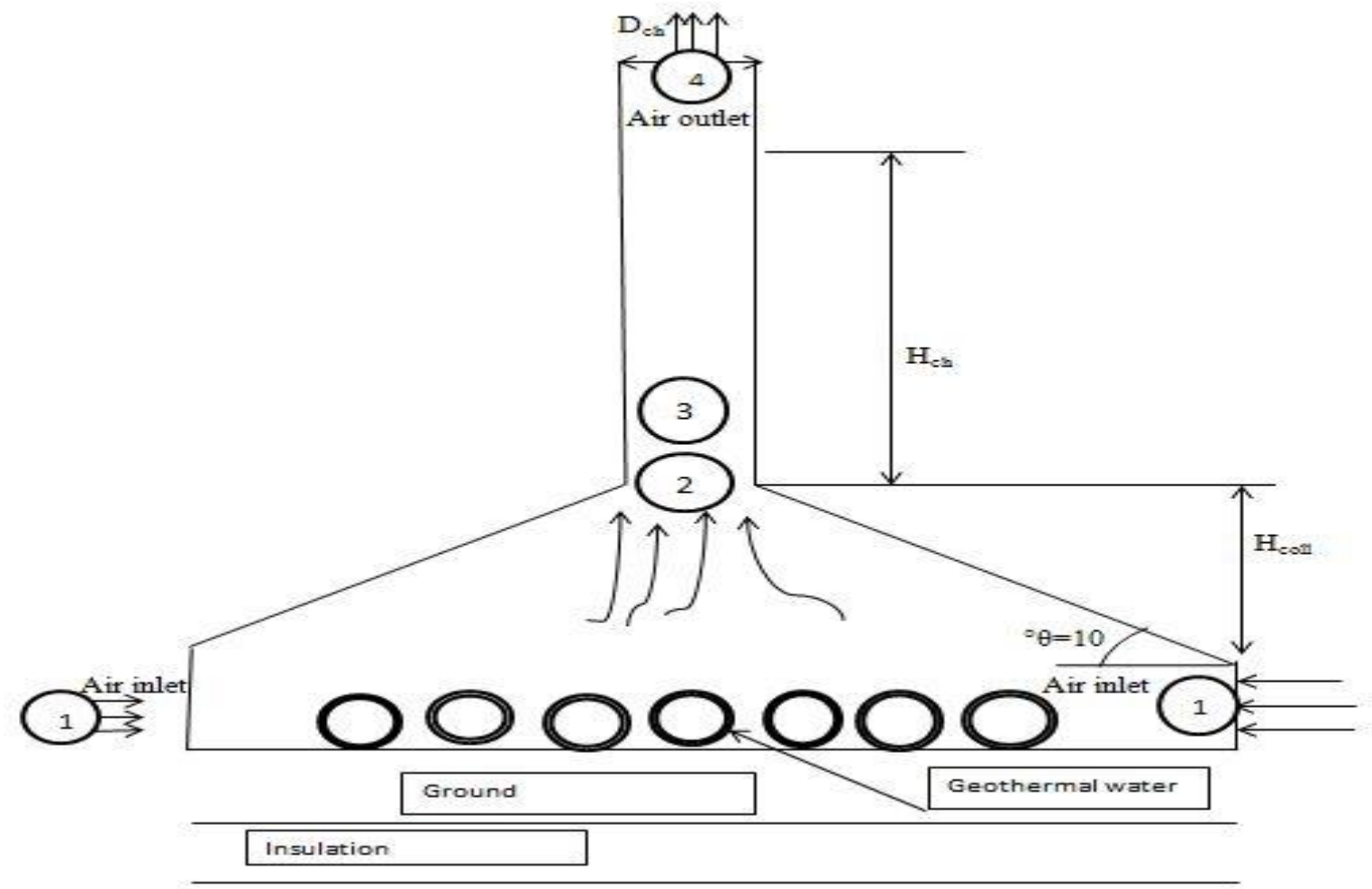

Figure 1.2 Geometry of plant with heat source 


\subsection{Energy Balance and Discretization of Collector Roof}

For roof:

$$
A_{\text {roof }} I_{\text {roof }}+q_{r, p r}+q_{r, g r}=q_{c o n, r f}+q_{c o n, r a}+q_{r, r s k y}+c_{p r} \rho_{r} \frac{d T_{r}}{d t} 2 \pi r_{r} d r_{r} z_{r}
$$

For air

$$
\mathrm{mc}_{\mathrm{p}} \frac{d T_{\mathrm{f}}}{d t}=q_{c o n, r f}+q_{c o n, p f}+q_{c o n, g f}-\dot{m} c_{p} \partial \frac{T_{f}}{\partial r} d r
$$

For geothermal pipe

$$
A_{\text {pipe }} I_{\mathrm{p}}+q_{r, r p}+q_{r, g p}+\frac{2 \pi l_{p} k_{p}}{\ln \left(\frac{r 2}{r 1}\right)}\left(T_{w}-T_{p}\right)=q_{c o n, p f}+c_{p p} \rho_{p} 2 \pi r_{p} \frac{d T_{p}}{d t} d r z_{p}
$$

For the ground storage

$$
A_{\text {ground }} I_{g}+q_{r, r g}+q_{r, p g}-A_{\text {ground }} h_{\text {con }, g f}\left(T_{g}-T_{f m}\right)=c_{p g} \rho_{g} 2 \pi r \frac{d T_{g}}{d t} d r d z
$$

\subsection{Available Pressure Capacity due to Slanted Roof and Tower}

The tower converts the temperature difference to the velocity of air. The rising of temperature creates the density difference in the collector that works as the driving force for fluid air. By taking the air as a working fluid, the whole pressure capacity converts to the moving pressure of airflow. In variable density assumptions, air is an ideal gas, and insignificant loss throughout the chimney wall. A mathematical equation developed to investigate the efficiency of the plant under conservation of energy and momentum principle.

The frictionless momentum equation express as;

$$
-\rho u \frac{d u}{d r}=\frac{d p}{d r}+\rho g \frac{d h}{d r}
$$

The increased pressure capacity to drive flow of air from the roof inlet to chimney outlet written as:

$\Delta P_{\text {poten }}=\frac{1}{2} \rho_{3} u_{3}{ }^{3}$

After integration of Eq. (1.9) can written as;

$$
\int_{1}^{3} \rho u d u=\frac{1}{2} \int_{1}^{3} \rho d u^{2}=p_{1}-p_{3}-g \int_{1}^{3} \rho d h
$$


The integral part of the Eq. (1.11) eliminated by inserting the average density of working fluid inside the roof into Eq. (1.10) can rewritten as:

$$
\frac{1}{2} \bar{\rho}\left(u_{3}^{3}-u_{1}^{3}\right)=p_{1}-p_{3}-g \bar{\rho} H_{\text {coll }}
$$

In addition, the expression Eq. (1.12) of the slanted collector pressure capacity $\Delta p_{\text {poten }}$ can write as;

$$
\Delta p_{\text {poten }}=p_{\infty 1}-p_{3}-\frac{\rho_{\infty 1}+\rho_{3}}{2} g H_{\text {coll }}
$$

At an arbitrary position, the height of collector described by radius and the inclination angle $\beta$ :

$h=H_{\text {coll }}-r \sin \beta$

The effective tower height $\mathrm{H}_{\text {eff }}$ for the Plant defined as the sum height of collector, $\mathrm{H}_{\text {coll, }}$ and the chimney height, Hchimney.

$H_{\text {eff }} H_{\text {coll }}+H_{\text {chimney }}$

The frictionless adiabatic flow of the dry air experience no entropy changes in the process and defined as:

$$
\begin{gathered}
\frac{P}{\rho^{\gamma}}=\text { constant } . . . \\
\rho=\frac{P}{R T} \ldots \ldots \ldots \ldots \\
\frac{p_{1}}{p_{2}}=\left(\frac{T_{1}}{T_{2}}\right)^{\frac{\gamma}{\gamma-1}} \ldots \ldots \\
\frac{\rho_{1}}{\rho_{2}}=\left(\frac{T_{1}}{T_{2}}\right)^{\frac{1}{\gamma-1}} \ldots . .
\end{gathered}
$$

The gas constant of dry air is $R=287 \mathrm{~J} / \mathrm{kg} . \mathrm{K}$. Temperature varies with altitude equal to $0.00975 \mathrm{~K} / \mathrm{m}$.

$$
T=T_{o}+\frac{g}{R} \frac{1-\gamma}{\gamma} h
$$

The relation between ambient air static temperature and height is described as: 
$\frac{T_{\infty}}{T_{\infty 0}}=1-\frac{g h}{c_{p} T_{\infty 0}}$

Where, $T_{\infty 0}$ is the atmospheric air temperature at sea level .

The variation of pressure due to gravity is given by:

$\frac{d p}{d z}=-\rho g$

After substitution of Eq. (1.18) into Eq. (1.21) we get

$p_{3}=p_{4}\left(1-\frac{g H_{s u t}}{c_{p} T_{3}}\right)^{\frac{-\gamma}{\gamma-1}}$

$p_{3}=p_{\infty 1}\left(\frac{1-\frac{g H_{e f f}}{c_{p} T_{\infty 1}}}{1-\frac{g H_{s u t}}{c_{p} T_{3}}}\right)^{\frac{\gamma}{\gamma-1}}$

$\frac{T_{4}}{T_{3}}=1-\frac{g H_{\text {sut }}}{c_{p} T 3}$

$\frac{T_{\infty}}{T_{\infty 1}}=1-\frac{g h}{c_{p} T_{\infty 1}}$

$\frac{p_{\infty}}{p_{\infty 1}}=\left(1-\frac{g h}{c_{p} T_{\infty 1}}\right)^{\frac{\gamma}{\gamma-1}}$

And the static pressure $p_{\infty 4}$ of dry atmosphere given by:

$p_{\text {static }, \infty 4}=p_{\text {static } \infty 33}\left(1-\frac{g H}{c_{p} T_{\infty 3}}\right)^{\frac{\gamma}{\gamma-1}}$

$\Delta p_{\text {poten }}=p_{\infty 1}\left(1-\left(\frac{1-\frac{g H_{\text {eff }}}{c_{p} T \infty_{3}}}{1-\frac{g H_{\text {sut }}}{c_{p} T_{3}}}\right)^{\frac{-\gamma}{\gamma-1}}\right)-\frac{g H_{\text {coll }} p_{\infty 1}}{2 R T_{\infty 1}}\left(1+\frac{T_{\infty 1}}{T_{3}}\left(\frac{1-\frac{g H_{\text {eff }}}{c_{p} T \infty_{3}}}{1-\frac{g H_{\text {sut }}}{c_{p} T_{3}}}\right)^{\frac{-\gamma}{\gamma-1}}\right)$

The pressure potential converted to dynamic pressure calculated as:

$\Delta p_{\text {total }}=\Delta p_{\text {poten }}-\Delta p_{\text {loss }}$ 
The thermal efficiency of the plant defined as the ratio of the fluid power of the air flow at the tower inlet to incoming solar radiation to air flow obtained from the slanted collector. It can also define as thermal energy to kinetic energy, which mainly determined by atmospheric temperature $\mathrm{T}_{\mathrm{o}}$ at sea level and chimney hight $\mathrm{H}_{\mathrm{ch}}[3,4]$.

$\eta_{c h}=\frac{\frac{1}{2} \dot{m}_{f} u_{f}{ }^{2}}{\dot{m}_{f} C p\left(T_{f 2}-T_{f 1}\right)}=\frac{g H_{c h}}{c_{p} T_{0}}$

The efficiency of collector roof is the ratio of useful energy transferred to the fluid air to the incoming solar radiation intercepted by the roof and the heat generation from the geothermal power plant waste heat.

$$
\eta_{\text {coll }}=\frac{Q_{\text {usefull }}}{I_{T} A_{\text {coll }}+Q_{\text {geo }}}=\frac{m_{f} c_{p f}\left(T_{f 2}-T_{f 1}\right)+0.5 * m_{f}\left(u_{2}^{2}-u_{1}^{2}\right)}{I_{T} A_{\text {coll }}+m_{w} c_{p w}\left(T_{w 2}-T_{w 1}\right)} \ldots \ldots \ldots \ldots \ldots \ldots \ldots \ldots \ldots \ldots \ldots \ldots \ldots \ldots
$$

\section{Result and Discussion}

The initial condition of the plant on Aluto Langano weather condition are tabulated in Table 3.1 by using this initial conditions numerical solutions are solved. The simulation result of the Figure 3.7 is tabulated in Table 3.2.

Table 3. 1 Assumed and Initial Condition

\begin{tabular}{|l|l|l|l|}
\hline \multicolumn{2}{|c|}{ Initial condition } & \multicolumn{2}{c|}{ Assumed condition } \\
\hline Parameter & Value & Parameter & $\begin{array}{l}\text { Assumed } \\
\text { value }\end{array}$ \\
\hline Ambient temperature, $\mathrm{Ta}$ & $18{ }^{\circ} \mathrm{C}$ & Roof temperature, $\mathrm{T}_{\mathrm{r}}$ & $50{ }^{\circ} \mathrm{C}$ \\
\hline Inlet air temperature, $\mathrm{T}_{\mathrm{f} 1}$ & $18^{\circ} \mathrm{C}$ & Outlet airtemperature, $\mathrm{T}_{\mathrm{f} 2}$ & $45^{\circ} \mathrm{C}$ \\
\hline $\begin{array}{l}\text { Inlet geothermal water } \\
\text { temperature, } \mathrm{T}_{\mathrm{w} 1}\end{array}$ & $90^{\circ} \mathrm{C}$ & Ground temperature, $\mathrm{Tg}$ & $60^{\circ} \mathrm{C}$ \\
\hline $\begin{array}{l}\text { Outlet geothermal water } \\
\text { temperature, } \mathrm{T}_{\mathrm{w} 2}\end{array}$ & $\mathrm{Ta}+20^{\circ} \mathrm{C}$ & $\begin{array}{l}\text { Geothermal water pipe } \\
\text { temperature, } \mathrm{Tp}\end{array}$ & $55^{\circ} \mathrm{C}$ \\
\hline $\begin{array}{l}\text { Mass flow rate of } \\
\text { geothermal water, } \dot{m}_{w}\end{array}$ & $62.5 \mathrm{~kg} / \mathrm{s}$ & Mass flow rate of fluid air, $\dot{m}_{f}$ & $1525 \mathrm{~kg} / \mathrm{s}$ \\
\hline $\begin{array}{l}\text { Specific heat capacity of } \\
\text { water }\end{array}$ & $4190 \mathrm{~J} / \mathrm{kg} . \mathrm{K}$ & & \\
\hline
\end{tabular}


Table 3. 2 The Output Parameter at Each Section of Plant

\begin{tabular}{|l|c|c|c|c|}
\hline State & Pressure $\mathbf{( P a )}$ & $\begin{array}{l}\text { Temperature } \\
\left({ }^{\circ} \mathbf{K}\right)\end{array}$ & Density $\mathbf{( k g / \mathbf { m } ^ { \mathbf { 3 } }}$ & Velocity $\mathbf{( m / s )}$ \\
\hline state1 & 90000 & 293 & 1.0703 & 3 \\
\hline state2 & 89901 & 318 & 0.98505 & 15.801 \\
\hline state3 & 89783 & 319 & 0.98067 & 7.909 \\
\hline state4 & 99044 & 317.1 & 1.0883 & 14.936 \\
\hline & $\Delta \mathrm{p}_{\text {poten }}=182.82 \mathrm{~Pa}$ & $\Delta \mathrm{p}_{\text {turb}=121.88 \mathrm{~Pa}}$ & $\Delta \mathrm{p}_{\text {loss }}=60.94 \quad \mathrm{~Pa}$ & $\Delta \mathrm{P}_{\text {load }}=123.59 \mathrm{~kW}$ \\
\hline
\end{tabular}

In Figure 3.1, four Figures plotted together which shows annual temperature variation of roof, ground, fluid airflow and pipe. The highest fluid air temperature observed in the month of November, December and January; which is approximately $323.3^{\circ} \mathrm{K}$. The minimum temperature observed in august. The temperature profile of all figures is similar in shape as shown, which shows the ground temperature is the maximum observed temperature because of the ground is acts as absorber in the system. It absorbs the incoming solar radiation and emits back to the collector roof and fluid air in the collector.

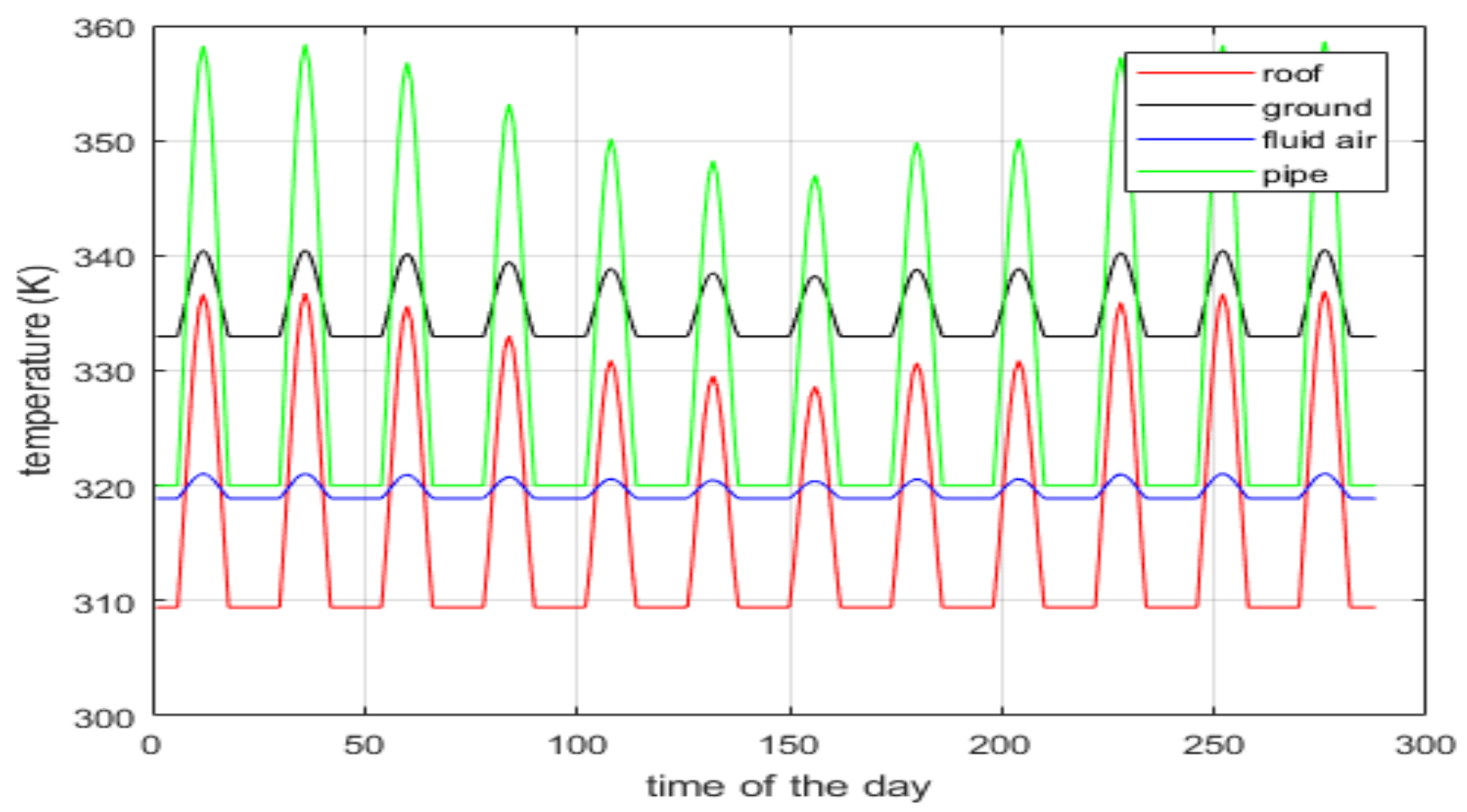

Figure 3. 1 Annually Temperature Variation of Roof, Ground, Fluid Air and Pipe 
In Figure 3.3, the daily variations of the representative day of January are plotted. The maximum temperature observed in the time between 10 A.M and 13 P.M for all graphs as shown, which is the maximum solar radiation, occurred. The temperature range of the fluid air is smaller than that of others; this indicates the power output of the plant is nearly constant throughout the day. To show the effect of geothermal water waste heat on the fluid air, Figure 3.2 and Figure 3.3 compared. The increasing recorded temperature is the combined effect of solar radiation and geothermal water waste heat from geothermal power plant.

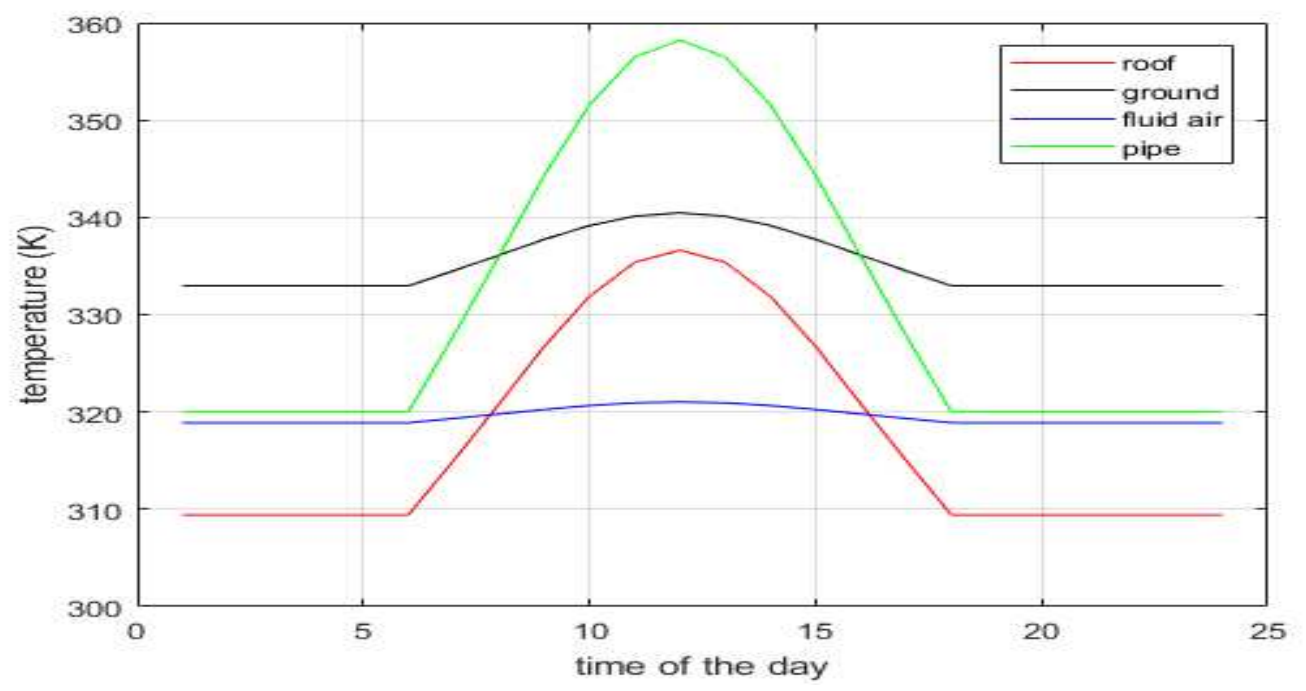

Figure 3. 2 Daily Temperature Variation of Roof, Ground, Fluid Air and Pipe

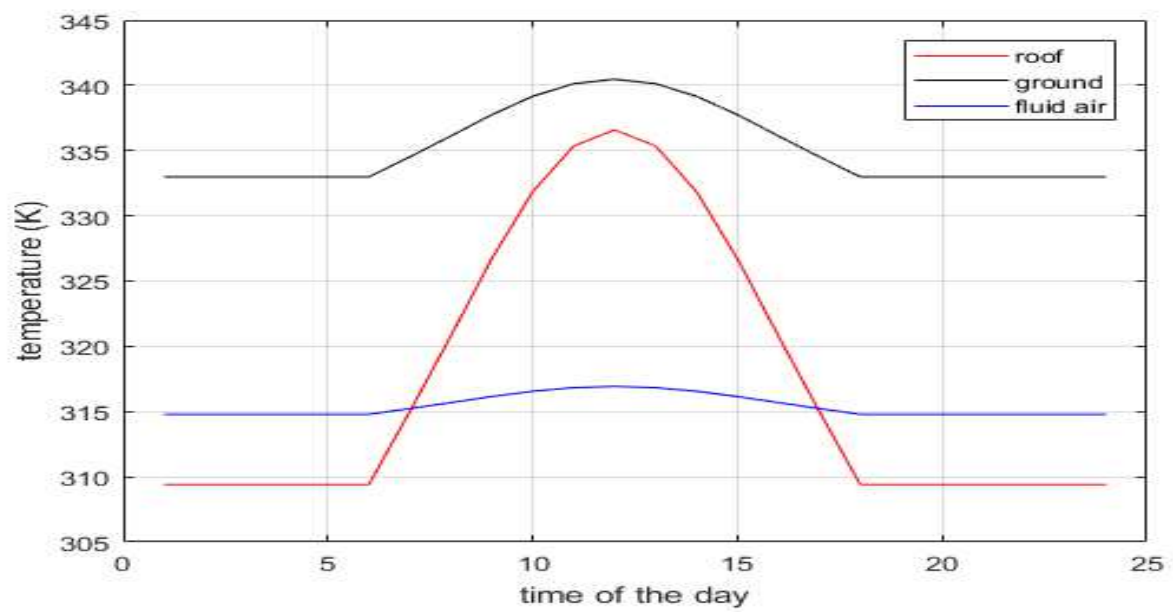

Figure 3. 3 The Output Temperature of Fluid Air without Geothermal Water 
Figure 3.4 indicates effect of solar insolation and roof radius on temperature graph air inside collector. keeping incoming radiation constant, the temperature of working fluid increases towards the collector outlet and reach maximum at collector outlet. Figure 3.4 also imply that, for the same collector radius increasing the incoming insolation increases air temperature. When solar radiation increases the collector surface temperature increases and hence the fluid air temperature. But as the incoming insolation above some level, the collector surface temperature increases more and then high convection occurs which results in decrease the mass flow rate of fluid air in the roof.

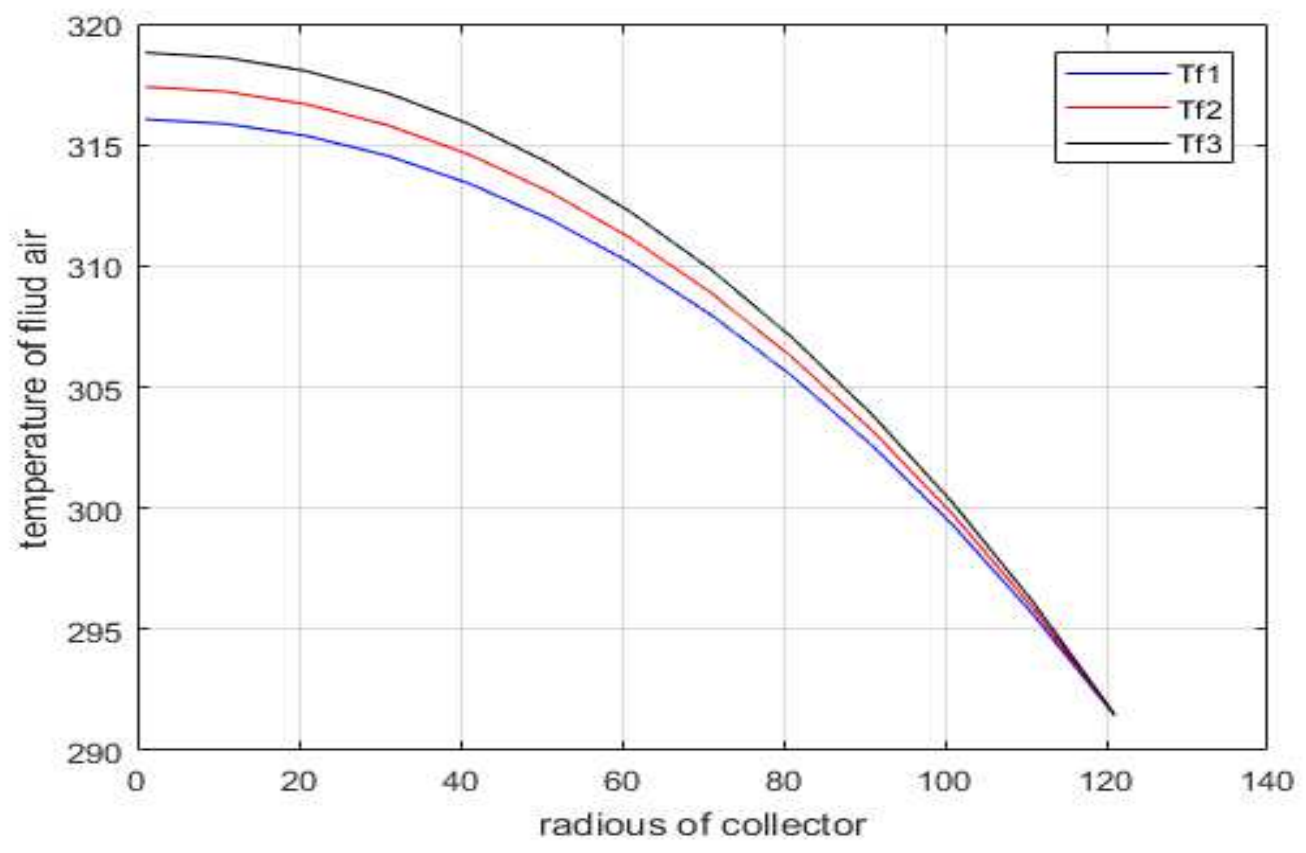

Figure 3. 4 Temperature of Fluid Air at any Radius of Collector

Figure 3.5 shows the static pressure profile, which decreases towards the collector out let and the minimum value observed at the chimney base. It also demonstrates that keeping collector radius is constant and incoming radiation results in a decrease in the static pressure. Figure 3.7 shows the air velocity profile through the collector. The velocity increases through the collector towards the collector outlet radius, but it increases rapidly at chimney base. When the collector radius is constant, an increase of solar radiation causes an increase of the air velocity. Examining the effect of collector radius on static temperature and velocity, the trend developing in Figure 3.5 and 3.7 respectively, have the same effect with the pressure and velocity graphs [5]. 


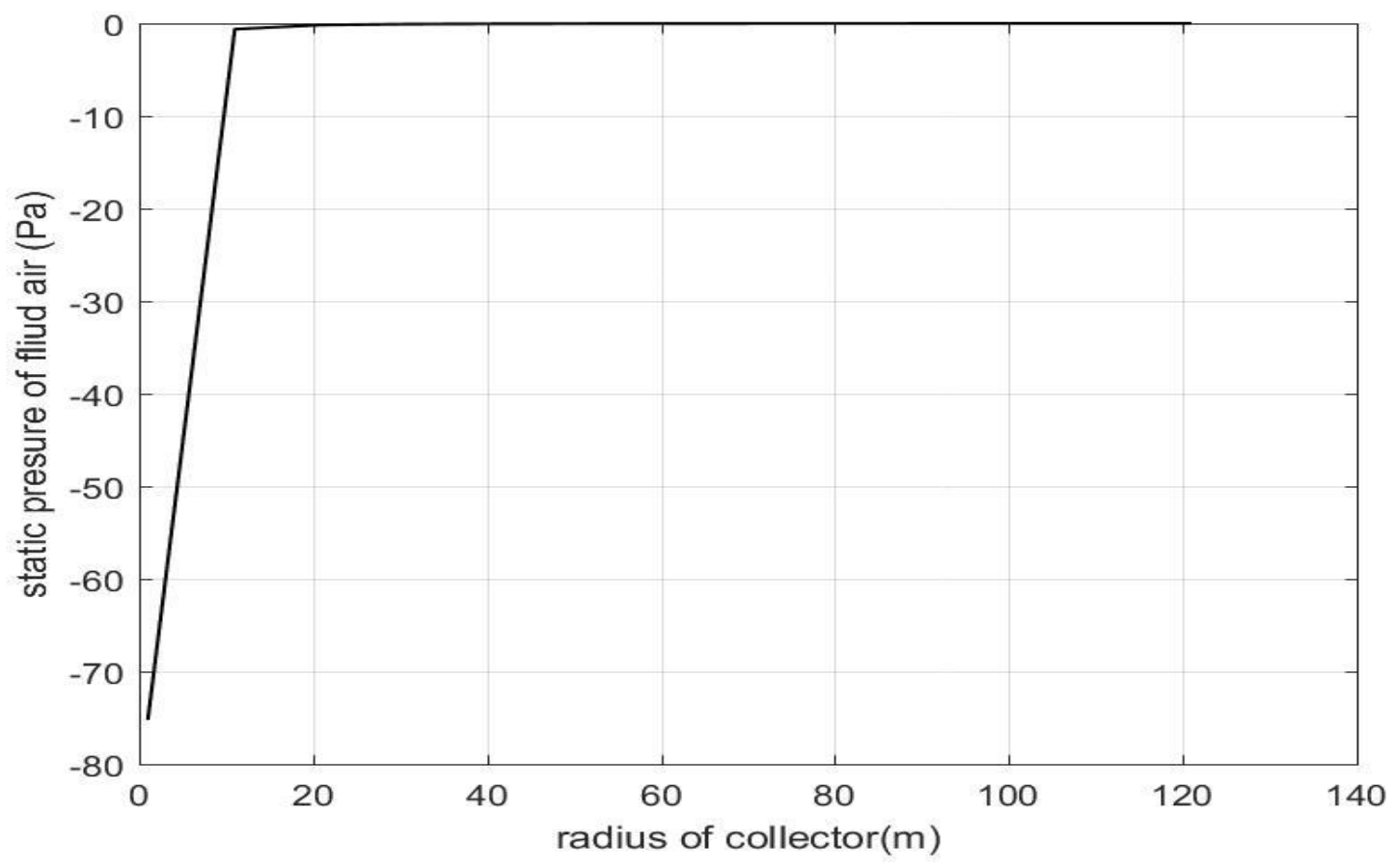

Figure 3. 5 Static Pressure versus Radius of Collector

The effect of changing dimensions of the solar chimney power plant on the power generation ranging from 60 to $120 \mathrm{~m}$ and chimney height from 50 to $450 \mathrm{~m}$ is shown in Figure 3.6 below. These results demonstrate that the larger the collector size and the higher the chimney height is, the greater the power generation will be. it is also evident that the power generation of solar chimney increases nonlinearly with the increase of collector diameter and chimney height. It increases sharply when the sizes of collector and the 54 chimney are small, but slowly with an increase in size. in this study about $123 \mathrm{~kW}$ electric power can produced in the solar chimney when the diameter of the collector is $244 \mathrm{~m}$, and the chimney height is $194 \mathrm{~m}$. 


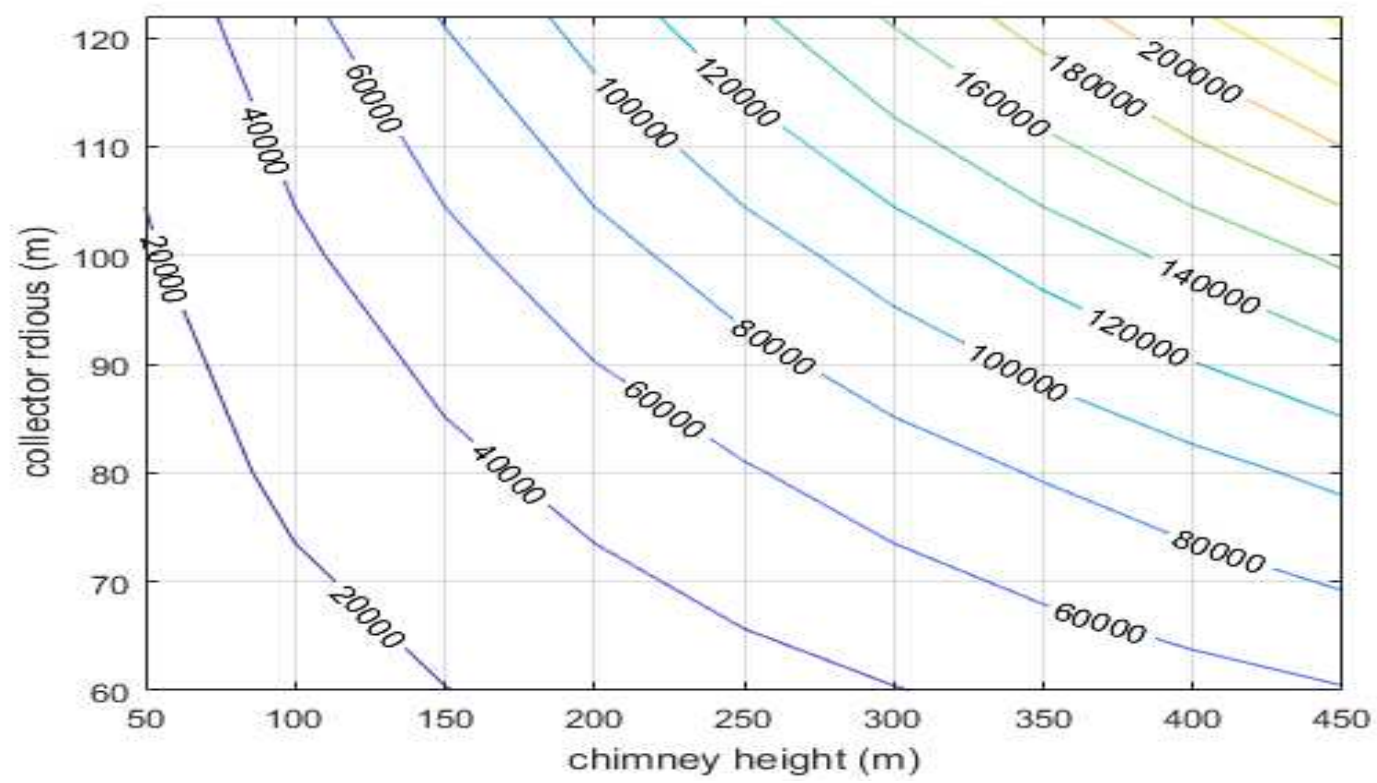

Figure 3. 6 Power Output versus Chimney Height and Collector Radius

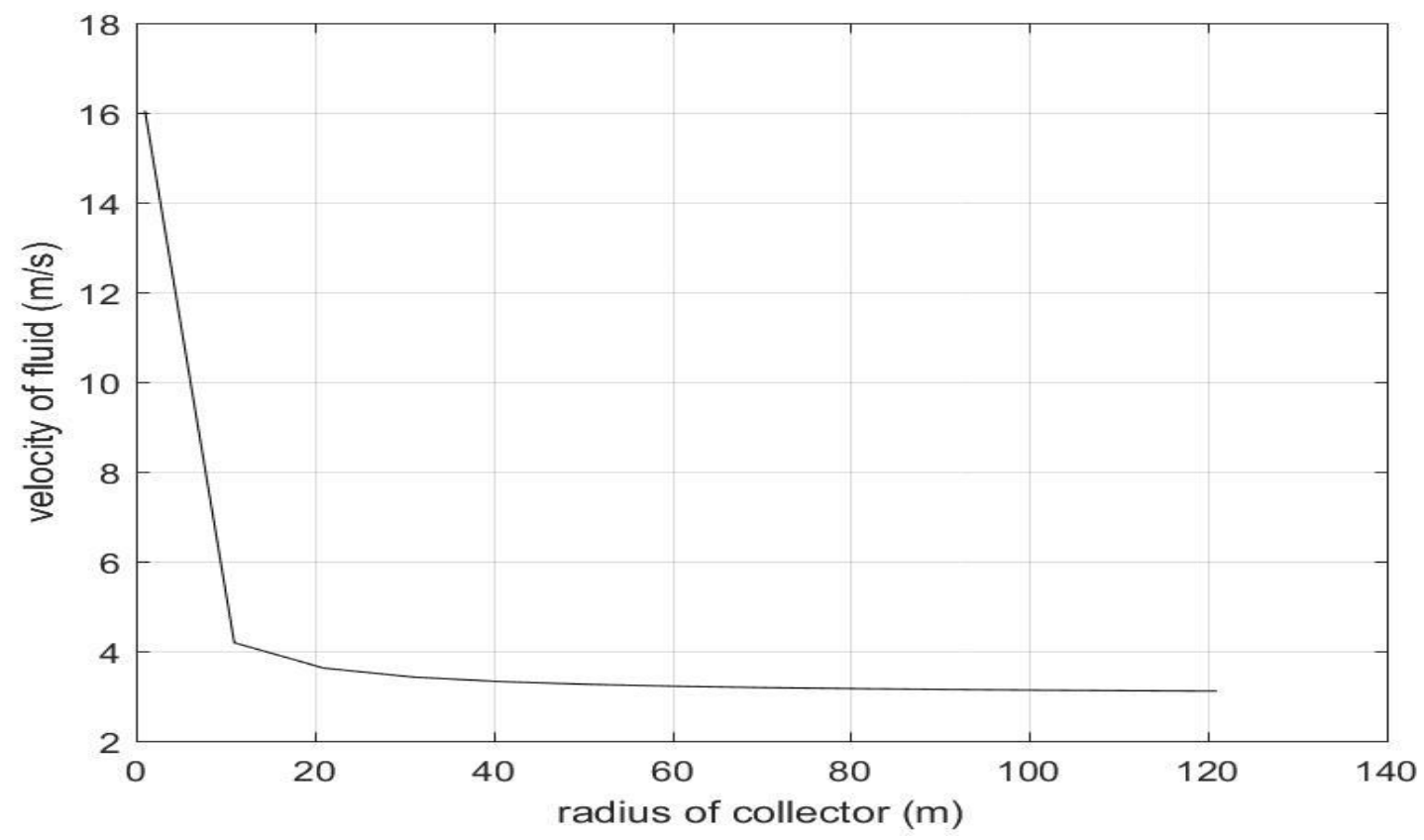

Figure 3. 7 Velocity of Fluid Air versus Radius 
Figure 3.8 presents the efficiency is improved due the use of hybrid solar-geothermal energy from $32 \%$ to $43.58 \%$.

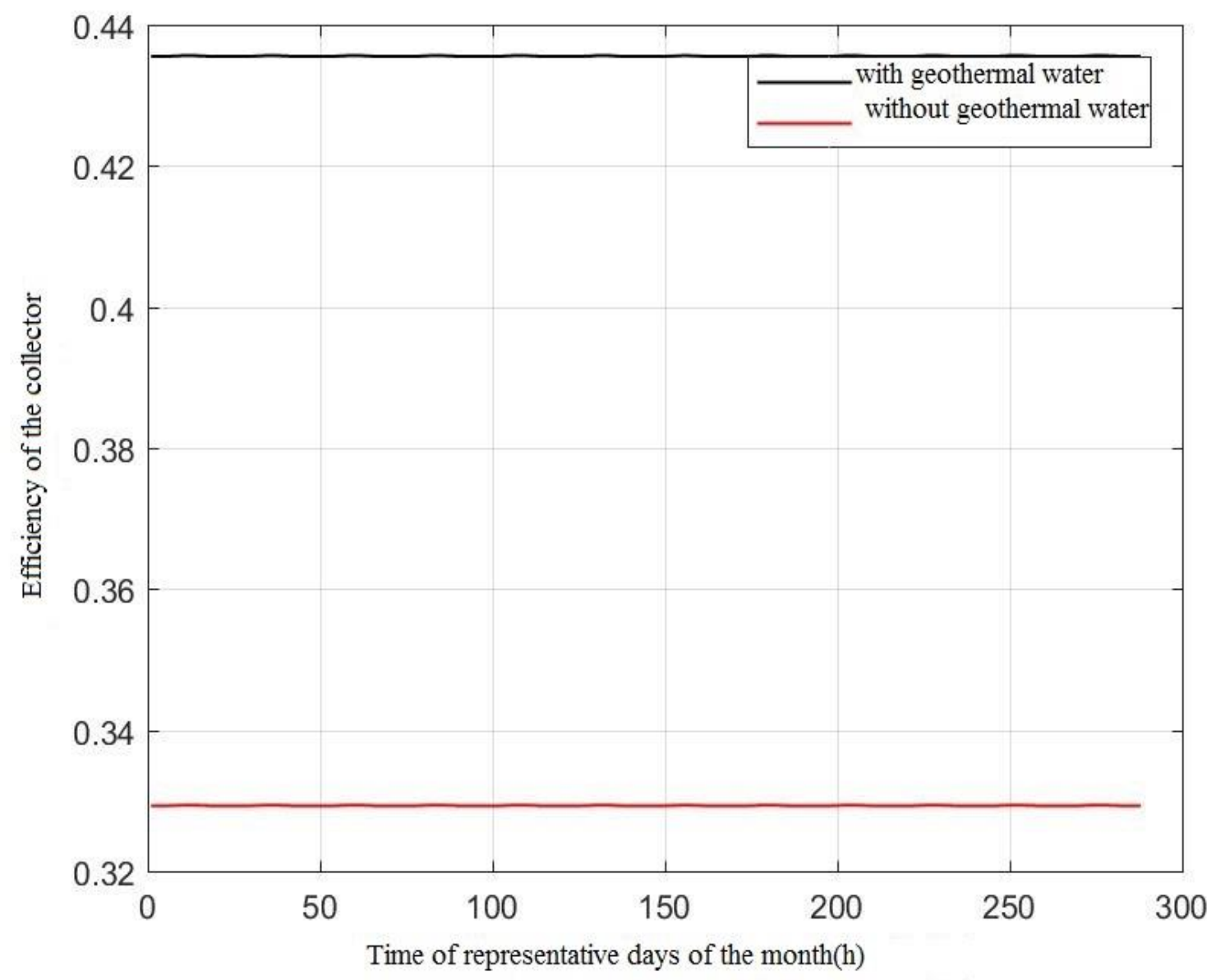

Figure 3. 8 Efficiency of Plant with and Without Geothermal Power Plant

\section{Conclusion}

In this work, the performance investigation of a solar chimney power plant using a heat source from geothermal power plant is done. The obtained results shows with waste heat of geothermal power plant with mass flow rate $62 \mathrm{~kg} / \mathrm{s}$ and $90{ }^{\circ} \mathrm{C}$, the collector temperature increases from 316 to $323 \mathrm{~K}$ with combined effect of geothermal water and solar radiation as shown in Figure 3.2 and Figure 3.3.

The change in temperature is $27^{\circ} \mathrm{C}$, which is $7{ }^{\circ} \mathrm{C}$ increment with Manzanares proto type as shown in Table 3.3. The maximum velocity achieved at the outlet of collector is $15.8 \mathrm{~m} / \mathrm{s}$ and $182.8 \mathrm{~Pa}$ 
potential pressures observed at the chimney inlet. The total pressure drop at the turbine is $120.4 \mathrm{~Pa}$ and 62.3 Pa pressure loss occurred due to inlet pressure loss to collector and turbine. The amount of power output increases from $50 \mathrm{~kW}$ to $123 \mathrm{~kW}$ and efficiency of the collector increases from $32 \%$ to $43.58 \%$. Hence, the total efficiency of the plant increased from $0.176 \%$ to $0.242 \%$.

Table 3. 3 Comparisons of this Work and Previous Works on Reference Plant

\begin{tabular}{|l|l|l|l|l|l|}
\hline Parameter & $\begin{array}{l}\text { Schalachi, } \\
\mathbf{2 0 0 5 )}\end{array}$ & $\begin{array}{l}\text { Asnaghi et al., } \\
(\mathbf{2 0 1 1})\end{array}$ & $\begin{array}{l}\text { Koonsrisuk and } \\
\text { Chitsomboon } \\
\text {,2003) }\end{array}$ & $\begin{array}{l}\text { In this } \\
\text { work }\end{array}$ & FLUENT \\
\hline $\mathrm{V}_{2}(\mathrm{~m} / \mathrm{s})$ & 15 & 16.2 & 15 & 15.58 & 15.4 \\
\hline $\mathrm{T}_{2}\left({ }^{\circ} \mathrm{K}\right)$ & 322 & & 314.5 & 320.2 & 325 \\
\hline$\Delta \mathrm{T}$ & 20 & 21.8 & 22 & 27 & 25 \\
\hline$\Delta \mathrm{p}_{\text {tur }}(\mathrm{Pa})$ & 74 & - & - & 130.70 & - \\
\hline$\Delta \mathrm{p}_{\text {poten }}(\mathrm{Pa})$ & - & 120 & 135 & 196.06 & - \\
\hline $\mathrm{p}_{\text {load }}(\mathrm{kW})$ & 48 & $265 \mathrm{MW} / \mathrm{yea}$ & 48.3 & 123.59 & -- \\
\hline $\boldsymbol{\eta}_{\text {coll }}$ & $32 \%$ & $35 \%$ & $37 \%$ & $43.58 \%$ & - \\
\hline $\boldsymbol{\eta}_{\text {ch }}$ & $0.65 \%$ & $0.65 \%$ & $0.65 \%$ & $0.653 \%$ & - \\
\hline $\boldsymbol{\eta}_{\text {tur }}$ & $85 \%$ & $85 \%$ & $85 \%$ & $85 \%$ & - \\
\hline $\boldsymbol{\eta}_{\text {tot }}$ & $0.176 \%$ & $0.1934 \%$ & $0.204 \%$ & $0.242 \%$ & - \\
\hline
\end{tabular}

The result of the study shows, the solar chimney power plant improved by combining waste heat from another power plant. The model results of this study validated with the previous works and good result has been get with improved efficiency and greater power output. 


\section{References}

1. Bilgen E, Rheault J. Solar chimney power plants for high latitudes. Solar Energy 2005; 79:449.

2. Sandeep K. Patel, Deepak Prasad and M. Rafiuddin Ahmed, Computational Studies on the Effect of Geometric Parameters on the Performance of a Solar Chimney Power Plant, Energy Conversion and Management 77 (2014) 424-431.

3. Pasumarthi N, Sherif SA. Experimental and theoretical performance of a demonstration solar chimney model, Part I: mathematical model develop-ment. Int J Energy Res 1998;22:277.

4. Haaf W. Solar towers, part II: preliminary test results from the Manzanares pilot plant, Solar Energy 2 (1984) 141-61.

5. Roozbeh Sangi, Majid Amidpour and Behzad Hosseinizadeh, Modeling and Numerical Simulation of Solar Chimney Power Plants, Solar Energy 85 (2011) 829-838.

6. Xinping Zhou and Yangyang Xu, Solar Updraft Tower Power Generation, Solar Energy 128 (2016) 95-125. 
Figures

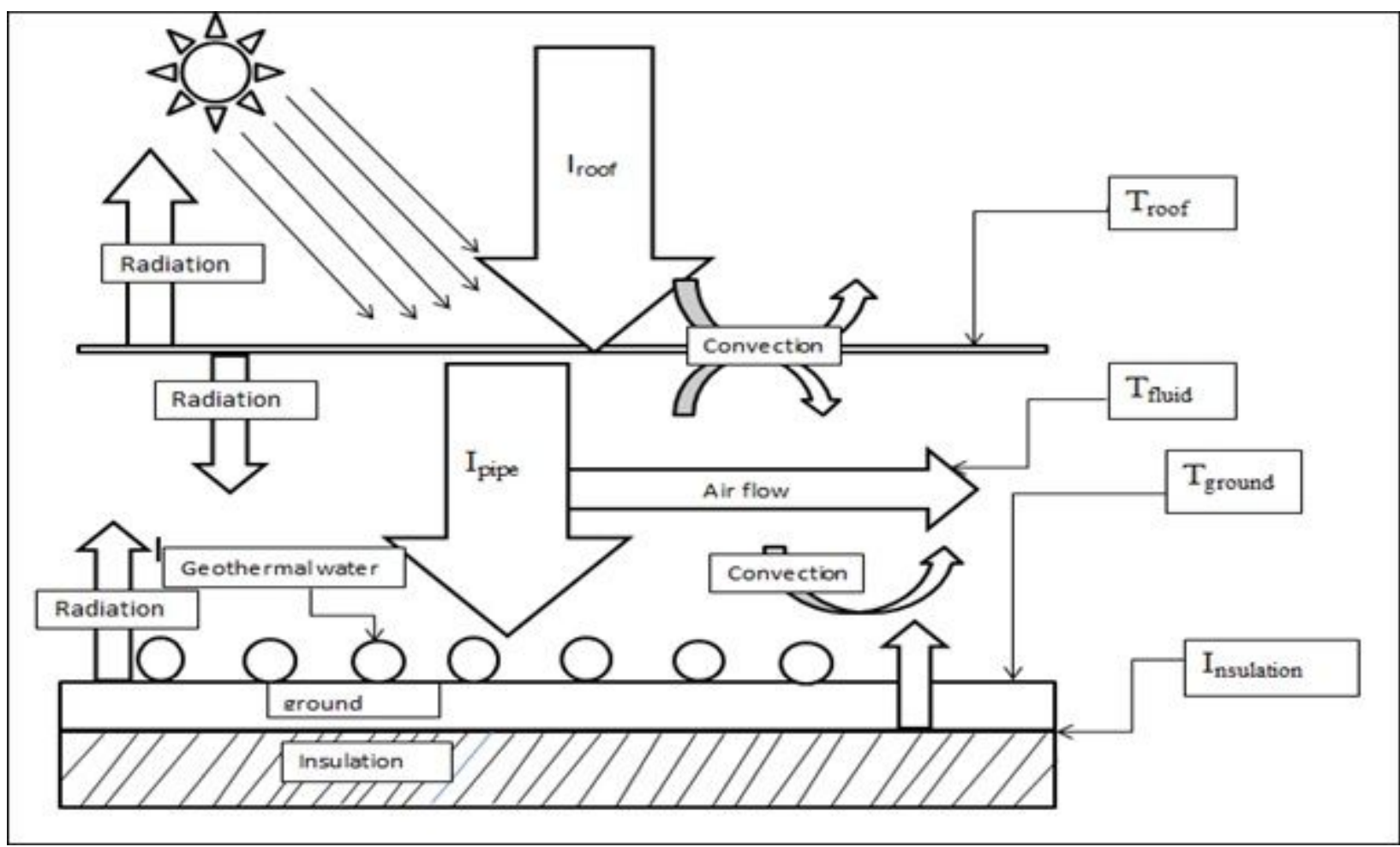

Figure 1

1. 1 Energy of collector roof

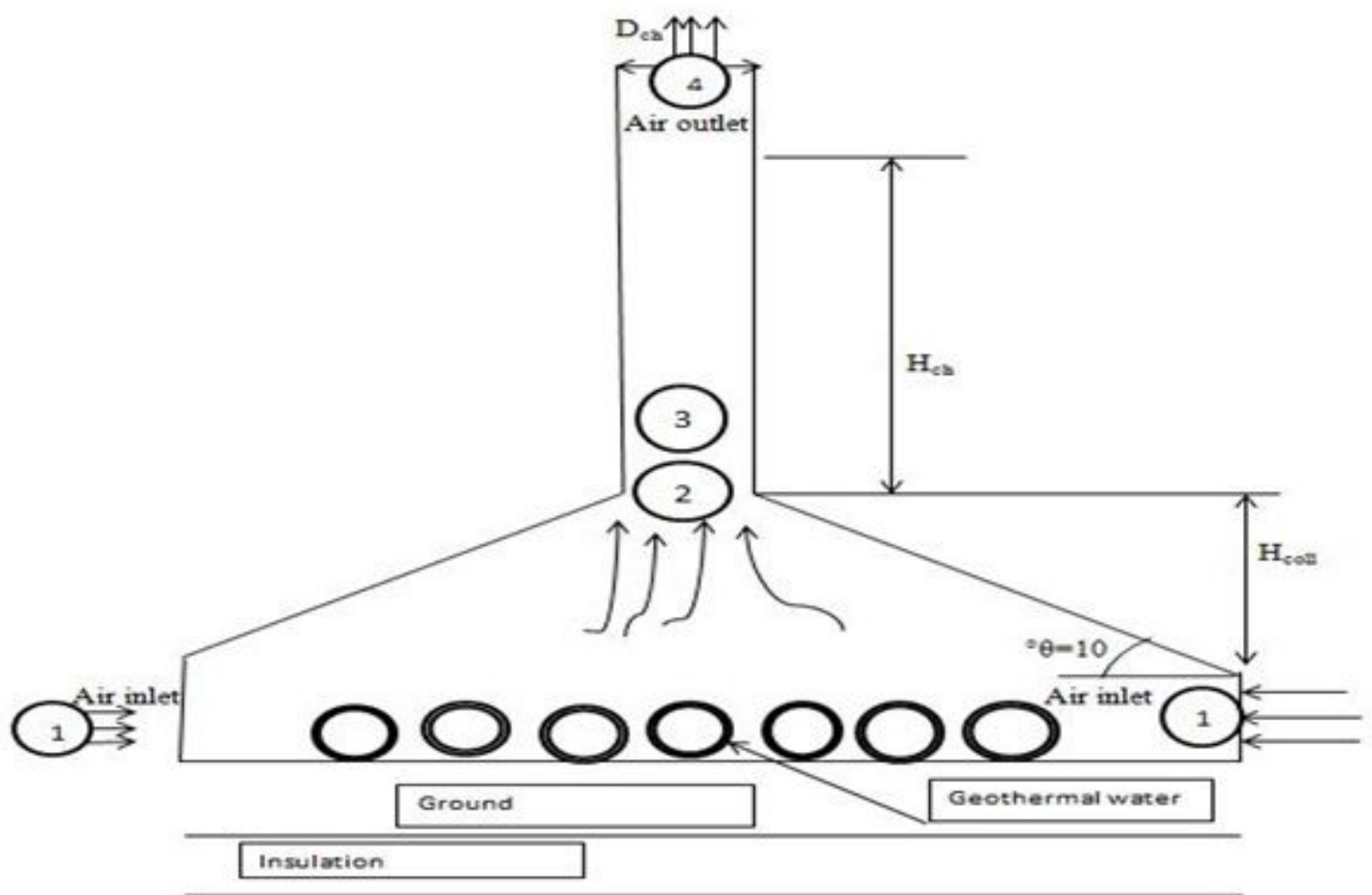

Figure 2 
1. 2 Geometry of plant with heat source

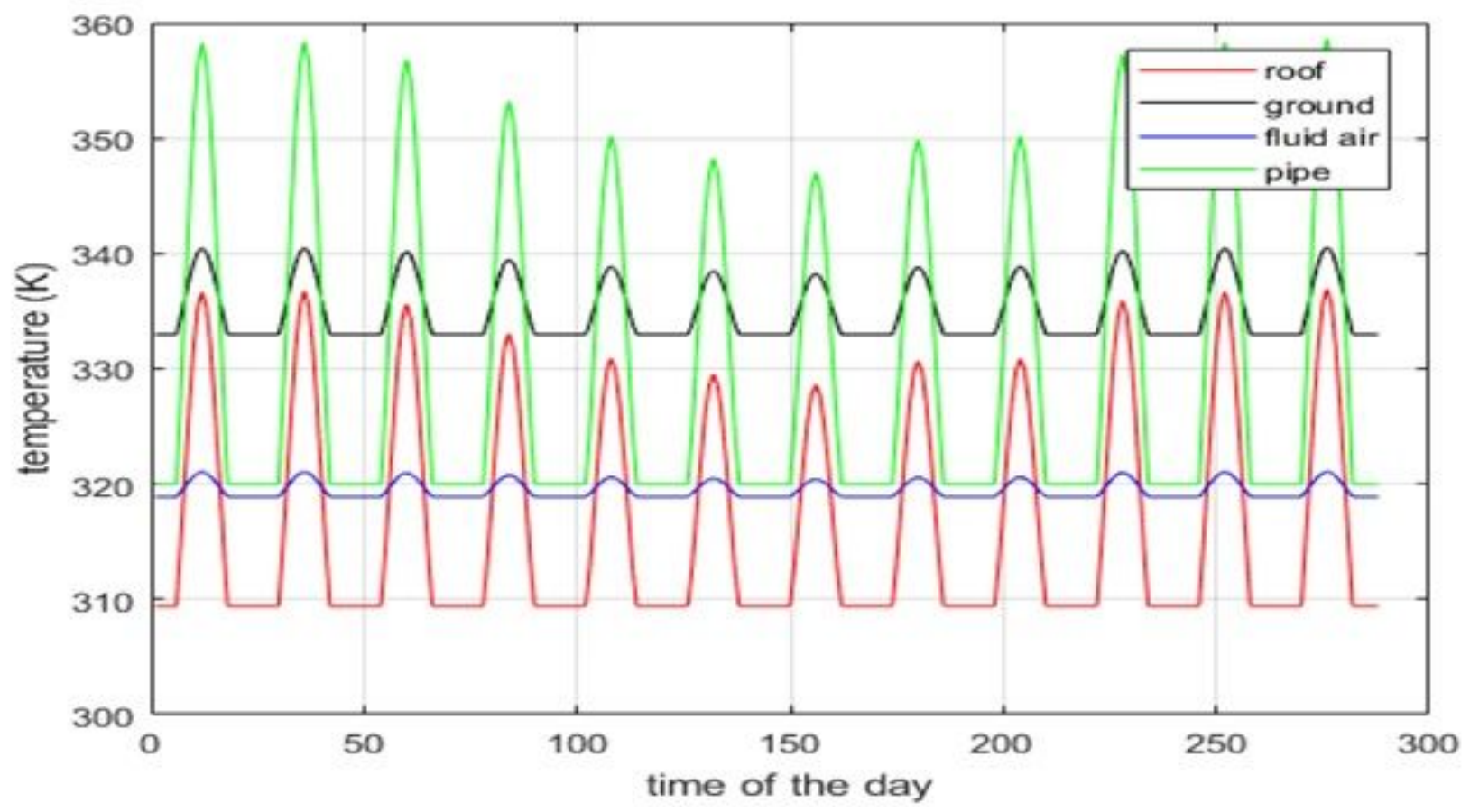

\section{Figure 3}

3. 1 Annually Temperature Variation of Roof, Ground, Fluid Air and Pipe

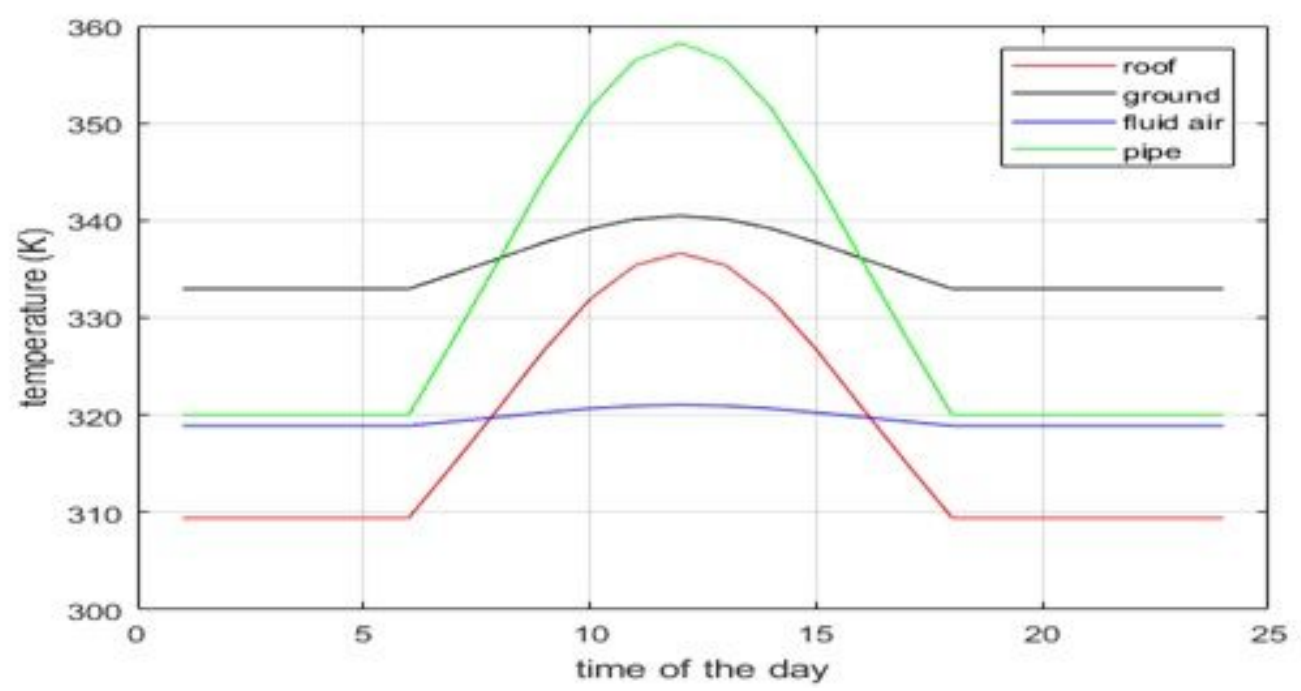

\section{Figure 4}

3. 2 Daily Temperature Variation of Roof, Ground, Fluid Air and Pipe 


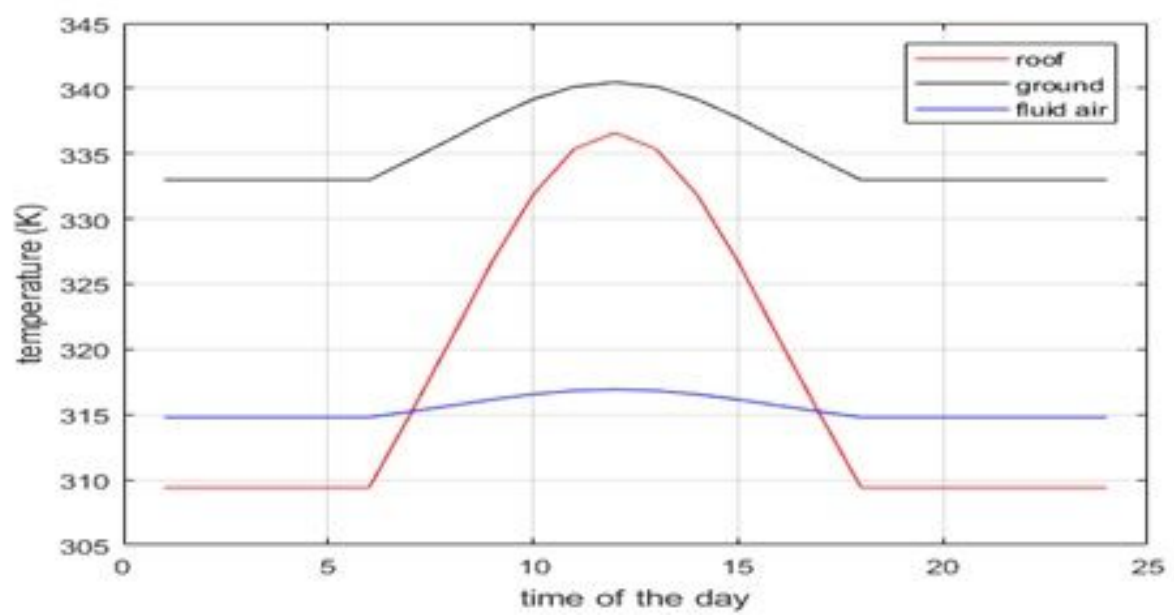

Figure 5

3. 3 The Output Temperature of Fluid Air without Geothermal Water

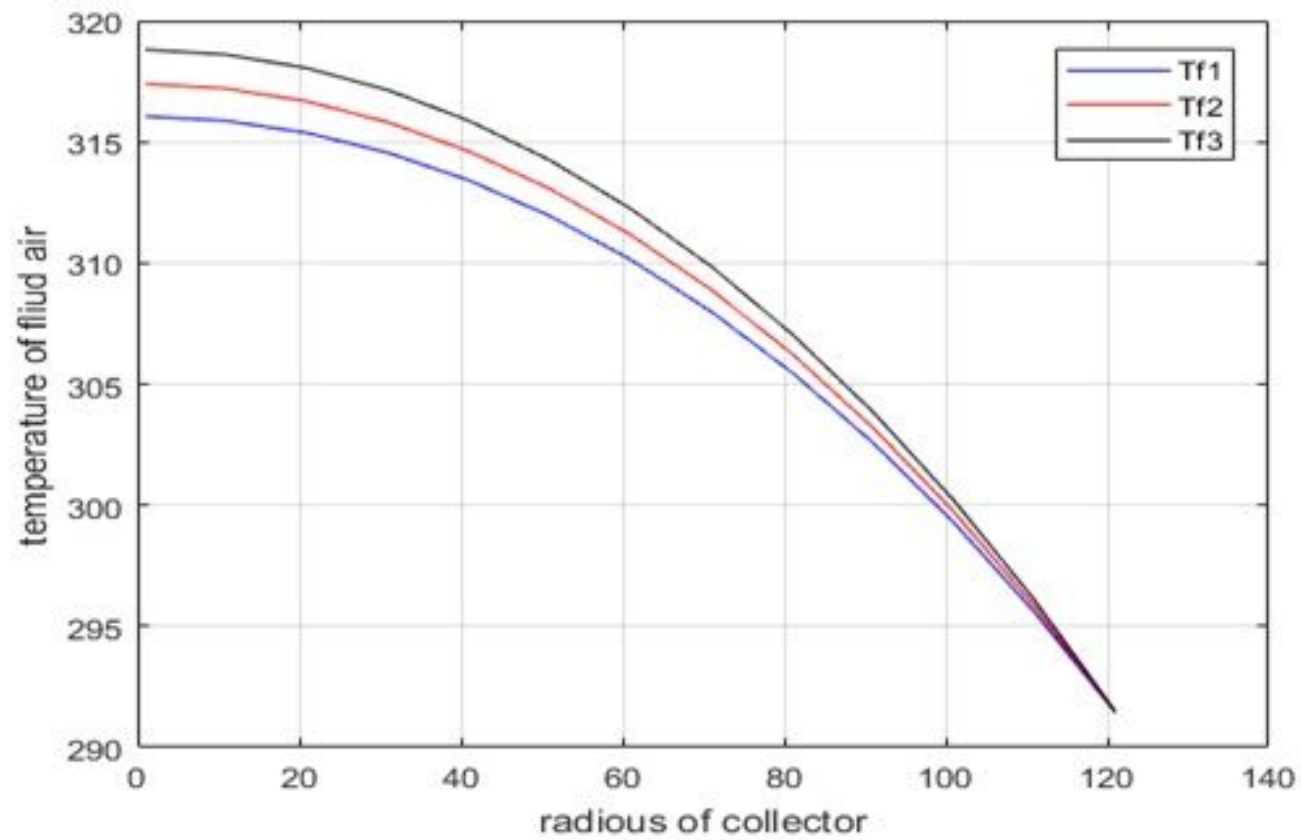

Figure 6

3. 4 Temperature of Fluid Air at any Radius of Collector 


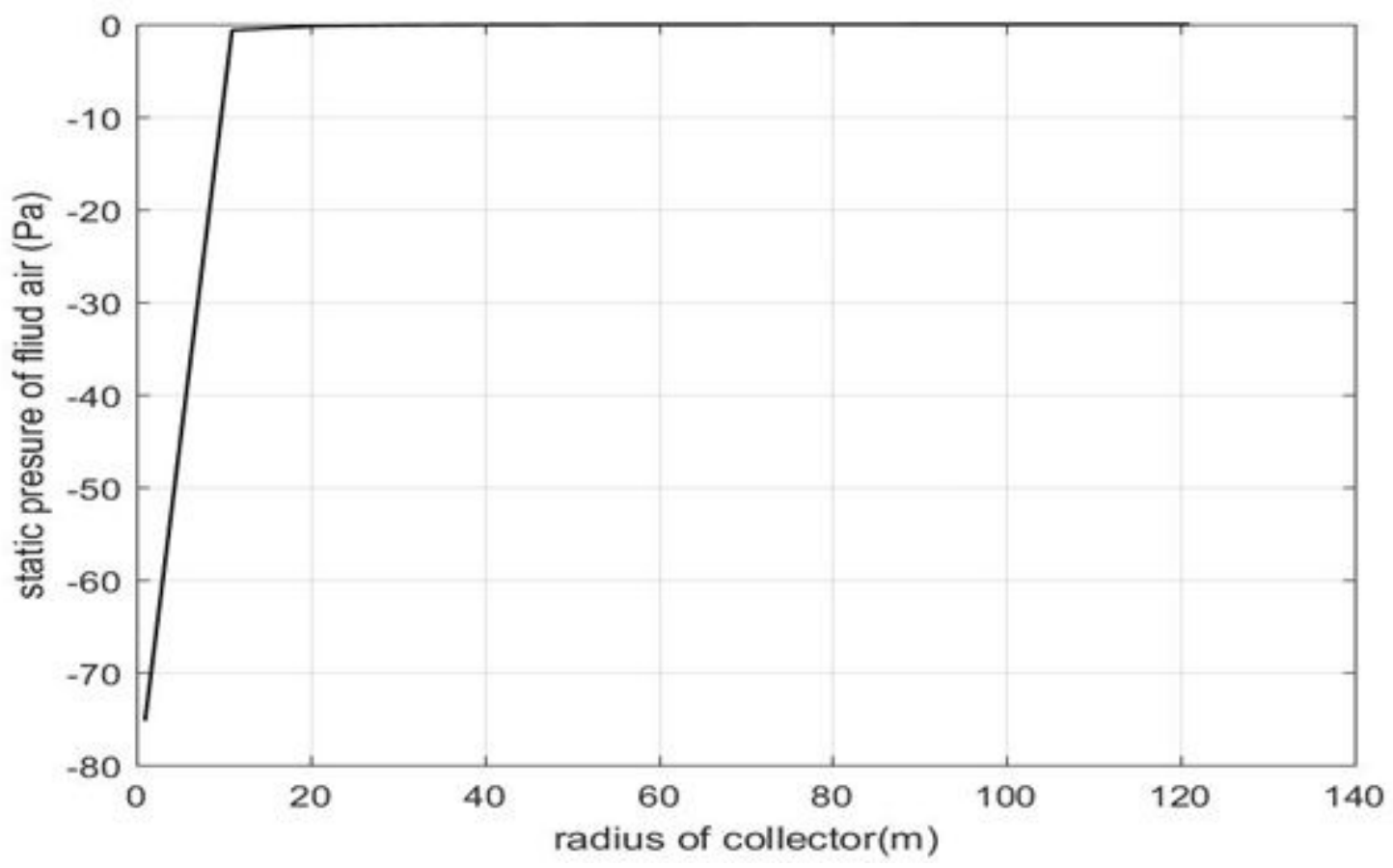

Figure 7

3. 5 Static Pressure versus Radius of Collector

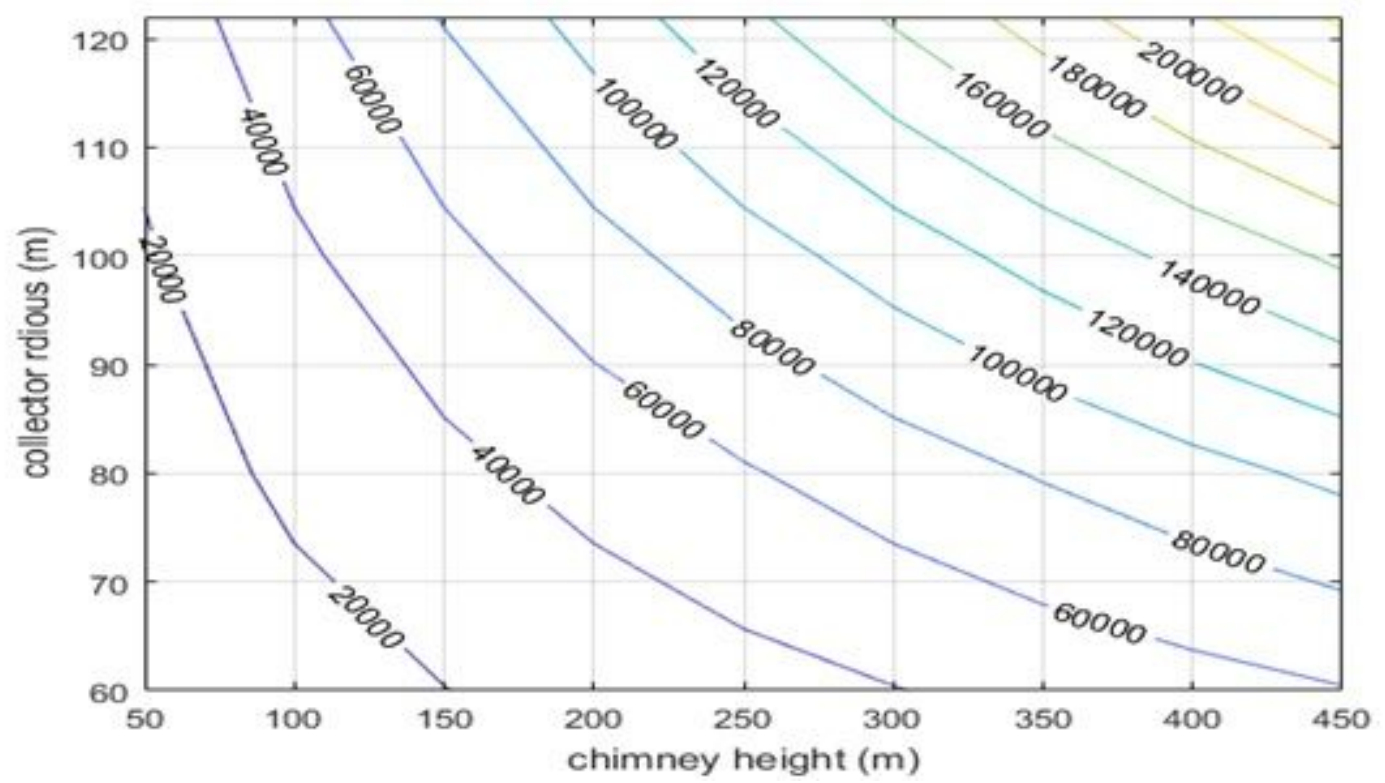

Figure 8

3. 6 Power Output versus Chimney Height and Collector Radius 


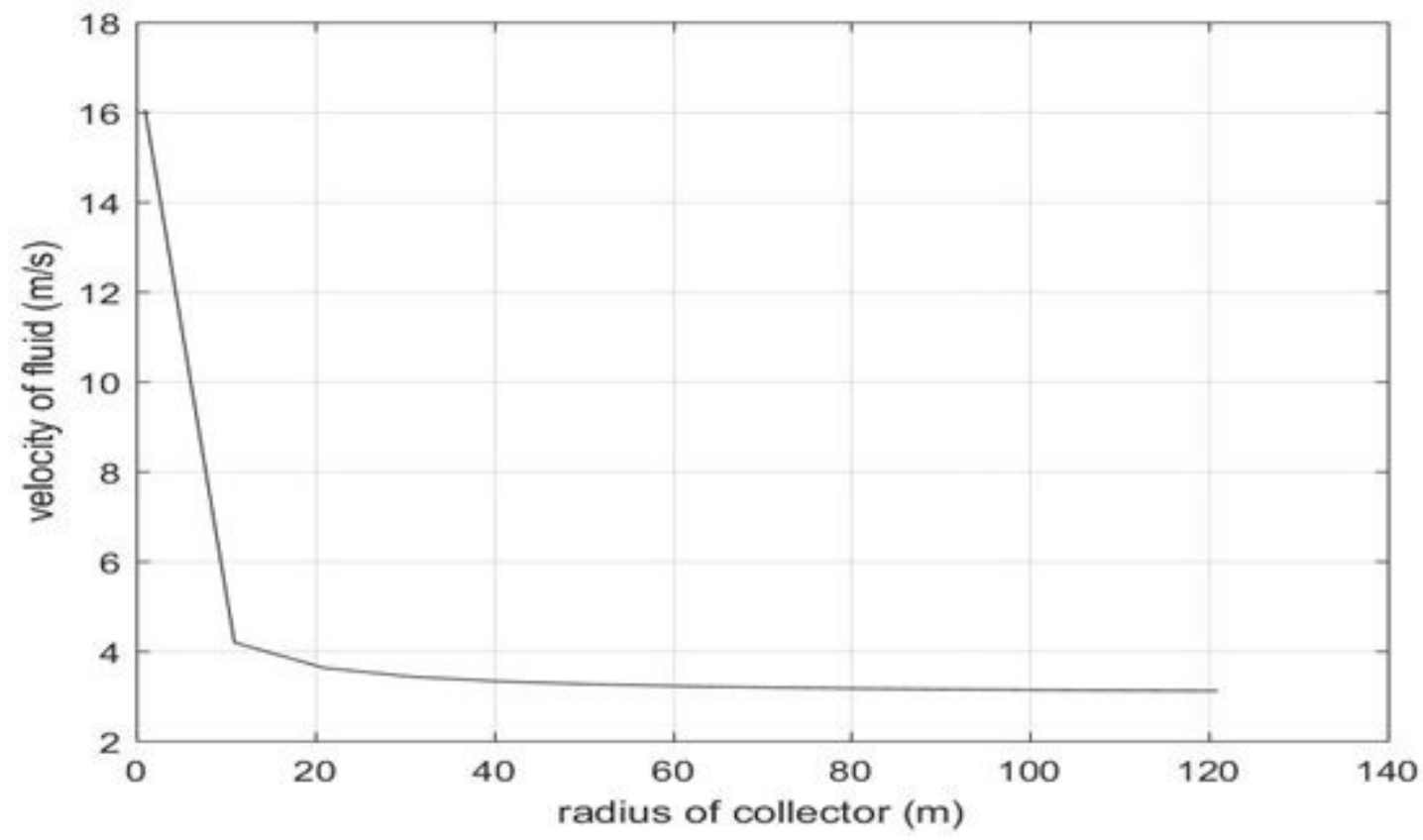

Figure 9

3. 7 Velocity of Fluid Air versus Radius

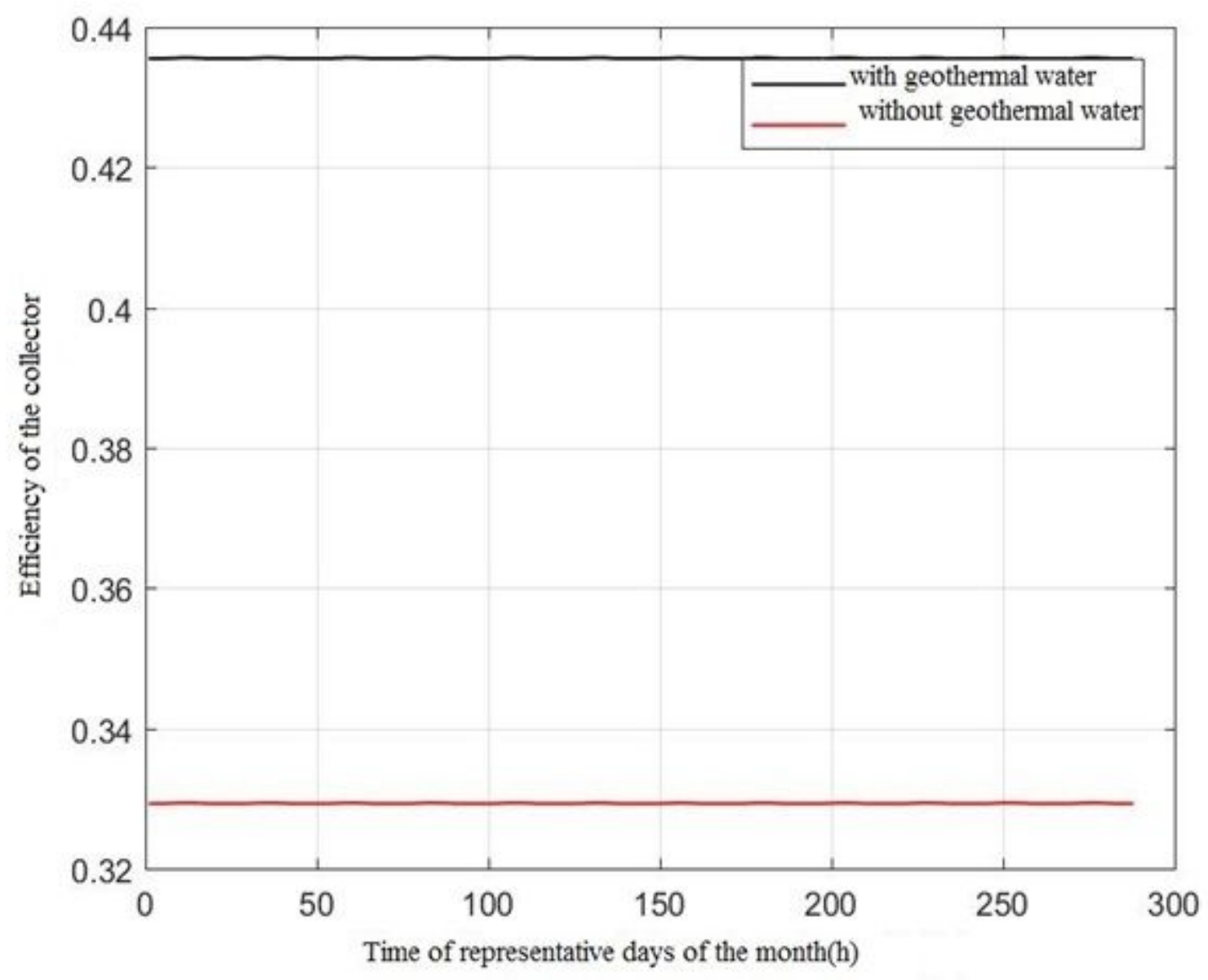

Figure 10 
3. 8 Efficiency of Plant with and Without Geothermal Power Plant 